\title{
Tanggung Jawab Direksi Perseroan Terbatas Atas Perbuatan Melawan Hukum Di Indonesia
}

\author{
Muhammad Rizqy Putra \\ Magister Hukum Fakultas Hukum Universitas Islam Indonesia Yogyakarta Indonesia \\ Jln. Cik Di Tiro No. 1 Yogyakarta Indonesia \\ mrizqyputra@gmail.com
}

\begin{abstract}
This research is motivated by legal problems that occur in Dasep Ahmadi and Hotasi Nababan, both of whom have committed acts against the law in their duties as directors who run the company. The problems to be answered in this research are how the responsibility of the board of directors of a limited liability company for unlawful acts committed by the board of directors in Indonesia and how is the legal remedies for the loss of the company due to unlawful acts committed by the board of directors in managing a limited liability company. This research using normative juridical method. The results of this study conclude that first, unlawful acts become a problem for the board of directors in managing the company, as a result the company suffers losses, the negligence of the directors in managing the company legally requires the directors to take full personal responsibility as stipulated in Article 97 paragraph (3) of the Company Law. Second, Dasep Ahmadi and Hotasi Nababan have carried out their personal responsibility in accordance with these provisions and for the fulfillment of compensation for the company, they can file a claim for compensation based on Article 61 paragraph (1) and Article 97 paragraph (6) of the Limited Liability Company Law and/or file a claim for compensation. losses based on unlawful acts as regulated in Article 1365 of the Civil Code.
\end{abstract}

Key Words: Limited liability company; responsibilities of directors; unlawful acts

\begin{abstract}
Abstrak
Penelitian ini dilatarbelakangi permasalahan hukum yang terjadi pada Dasep Ahmadi dan Hotasi Nababan, keduanya sama-sama telah melakukan perbuatan melawan hukum dalam tugasnya sebagai direksi yang mengurus perseroan. Permasalahan yang ingin dijawab dalam penelitian ini adalah bagaimana tanggung jawab direksi perseroan terbatas atas perbuatan melawan hukum yang dilakukan oleh direksi di Indonesia dan bagaimana upaya hukum atas kerugian perseroan akibat perbuatan melawan hukum yang dilakukan oleh direksi dalam mengurus perseroan terbatas. Penelitian menggunakan metode yuridis normatif. Hasil penelitian menyimpulkan, pertaman, bahwa perbuatan melawan hukum menjadi permasalahan bagi direksi dalam melakukan pengurusan perseroan, akibatnya perseroan mengalami kerugian, kelalaian direksi dalam pengurusan perseroan mewajibkan secara hukum direksi mengambil tanggung jawab penuh secara pribadi sebagaimana ketentuan Pasal 97 ayat (3) UU PT. Kedua, Dasep Ahmadi dan Hotasi Nababan telah melakukan tanggung jawab secara pribadi sesuai dengan ketentuan tersebut dan untuk pemenuhan ganti kerugian terhadap perseroan, bisa melakukan gugatan ganti kerugian berdasarkan Pasal 61 ayat (1) dan Pasal 97 ayat (6) UU PT dan/ atau mengajukan gugatan ganti kerugian berdasarkan perbuatan melawan hukum sebagaimana yang diatur Pasal 1365 KUHPerdata.
\end{abstract}

Kata-kata Kunci: Perseroan terbatas; perbuatan melawan hokum; tanggung jawab direksi 


\section{Pendahuluan}

Perseroan Terbatas merupakan badan hukum yang merupakan persekutuan modal, pada prosesnya ia didirikan berdasarkan perjanjian, yang melakukan kegiatan usaha dengan modal dasar yang seluruhnya terbagi dalam saham dan memenuhi persyaratan yang ditetaplan oleh Undang-Undang Nomor 40 Tahun 2007 tentang Perseroan Terbatas (UU PT), pengaturan tersebut dapat ditemui pada Pasal 1 UU PT. Perseroan terbatas sebagai badan hukum membutuhkan manusia guna melakukan pengurusan hak dan kewajiban yang dimilikinya, hal ini dikarenakan perseroan tidak bisa berdiri sendiri, tidak memiliki daya pikir dan kemampuan tanpa dibantu oleh peran manusia, maka dari itu senada dengan ketentuan Pasal 92 ayat (1) UU PT, bahwa yang bertugas untuk menjalankan pengurusan perseroan adalah direksi untuk kepentingan perseroan dan sesuai dengan maksud dan tujuan perseroan, imbasnya ialah segala bentuk tindakan direksi baik di dalam maupun di luar pengadilan adalah untuk dan atas nama serta tanggung jawab perseroan sebagai badan hukum.

Pengurusan perseroan oleh direksi tidak hanya mengacu sebatas apa yang telah diatur dalam UU PT, melainkan juga harus berpedoman pada anggaran dasar perseroan. Pengurusan perseroan oleh direksi wajib dilandasi oleh itikad baik, hal ini sesuai dengan apa yang diatur Pasal 97 ayat (2) UU PT. Praktiknya, direksi memiliki fungsi perwakilan (sebagaimana ketentuan Pasal 1 angka 5 UU PT) dan fungsi pengurusan (sebagaimana ketentuan Pasal 92 ayat (1) UU PT). Dalam tatanan teori, untuk menjalankan kedua fungsi tersebut direksi juga perlu memperhatikan doktrin hukum fiduciary duty dan business judgement rule.

Implementasi doktrin fiduciary duty dalam pelaksanaan tugas direksi terkait dengan 2 fungsi, yaitu fungsi manajemen dan fungsi representasi. Fungsi manajemen adalah tugas direksi memimpin perusahaan, Sedangkan fungsi representasi adalah tugas direksi mewakili perusahaan di dalam dan di luar perusahaan.

Business judgement rule timbul sebagai akibat telah dilaksanakannya fiduciary duty oleh seseorang direksi, yaitu prinsip duty of skill and care maka semua kesalahan yang timbul setelah dijalankannya prinsip ini, memperoleh konsekuensi direksi mendapat pembebasan tanggung jawab secara pribadi bila terjadi kesalahan dalam keputusannya tersebut. ${ }^{1}$ Erman Radjagukguk berpendapat bahwa direksi suatu perusahaan tidak dapat bertanggung jawab atas kerugian yang timbul dari suatu tindakan pengambilan keputusan, apabila tindakan tersebut didasarkan pada itikad baik dan hati-hati. Direksi

\footnotetext{
${ }^{1}$ Hendra Setiawan Boen, Bianglala Business Judgement Rule, PT Tatanusa, Jakarta, 2008, hlm. 100.
} 
mendapatkan perlindungan tanpa perlu memperoleh pembenaran dari pemegang saham atau pengadilan atas keputusan yang diambilnya dalam konteks pengelolaan perusahaan. Hal ini sering disebut sebagai doktrin Business judgement rule. ${ }^{2}$

Apabila ternyata pengurusan perseroan oleh direksi tidak dilandasi oleh itikad baik, sehingga menimbulkan kerugian terhadap perseroan, maka direksi bertanggung jawab secara pribadi atas kerugian perseroan, baik secara pidana maupun perdata. Dasar pertanggungjawaban penuh secara pribadi tersebut adalah kesalahan atau kelalaian direksi dalam menjalankan tugasnya yang tidak dilandasi dengan itikad baik, hal ini sesuai dengan ketentuan Pasal 97 ayat (3) UU PT, contohnya adalah ketika dalam menjalankan tugasnya direksi melakukan halhal yang bertentangan dengan ketentuan UU PT dan/atau anggaran dasar, perbuatan tersebut bisa saja dikategorikan sebagai perbuatan melawan hukum.

Berdasarkan pemaparan diatas, penulis mencoba mengkaji teori serta ketentuan-ketentuan hukum terkait dengan permasalahan hukum yang nyata terjadi, khususnya pada kasus yang melibatkan Dasep Ahmadi, Direksi PT. Sarimas Ahmadi Pratama dan juga Hotasi Nababan, Direksi PT. Merpati Nusatara Airline (Persero).

Pada kasus pertama, Dasep Ahmadi, berdasarkan Putusan Pengadilan Tindak Pidana Korupsi pada Pengadilan Negeri Jakarta Pusat Nomor: 140/Pid.Sus/TPK/2015/PN.Jkt.Pst. dijatuhi pidana penjara selama 7 tahun akibat dinyatakan secara sah dan meyakinkan bersalah melakukan tindak pidana korupsi sebagaimana yang diatur dan diancam pidana dalam Pasal 2 ayat (1) jo. Pasal 18 UU Nomor 31 Tahun 1999 tentang Pemberantasan Tindak Pidana Korupsi sebagaimana yang diubah dengan UU Nomor 20 Tahun 2001.

Kronologisnya, mewakili PT. SAP, sebagai direksi, Dasep Ahmadi yang ditunjuk sebagai rekanan sekaligus pengembang Mobil Listrik Nasional dalam bentuk pembuatan Prototype Electric Bus dan Executive Electric Car untuk kegiatan APEC XXI 2013, mengadakan perjanjian kerjasama antara lain dengan PT. Perusahaan Gas Negara (Persero), PT. Bank Rakyat Indonesia (Persero) dan PT. Pratama Mitra Sejati selaku cucu perusahan PT. Pertamina (Persero).

Pada prosesnya, Dasep Ahmadi yang bertindak dan untuk atas nama PT. SAP telah melakukan kesalahan serta kelalaian dengan menyediakan mobil listrik yang ternyata hasil rekayasa dan tidak laik untuk dipergunakan, selain itu perbuatan Dasep Ahmadi tersebut bertentangan dengan peraturan perundangan yang berlaku sehingga menimbulkan kerugian terhadap PT. SAP.

2 Sentosa Sembiring, Hukum Perseroan Terbatas Tentang Hukum Perusabaan, Nuansa Aulia, Bandung, 2012, hlm. 105. 
Berbeda dengan Dasep Ahmadi, Hotasi Nababan selaku Direksi PT. MNA, pada tingkat pertama berdasarkan Putusan Pengadilan Tindak Pidana Korupsi pada Pengadilan Negeri Jakarta Pusat Nomor: 36/Pid.Sus/TPK/2015/PN.Jkt.Pst. justru divonis bebas meski mendapatkan dakwaan yang sama, Alasan utama pembebasan ia dari dakwaan adalah penilaian bahwa Hotasi Nababan telah melakukan pengurusan PT. MNA dengan berhati-hati, beritikad baik dan demi kepentingan PT. MNA. Walaupun pada akhirnya, Hotasi Nababan berdasarkan putusan kasasi Mahkamah Agung RI Nomor: 417.K/Pid.Sus/2014 divonis pidana penjara selama 4 tahun dikarenakan secara sah dan meyakinkan bersalah melakukan tindak pidana korupsi secara bersama.

Kronologisnya, Hotasi D.P. Nababan selaku Direktur Utama dari PT. MNA pada saat itu hendak membuat kebijakan untuk menyelamatkan kondisi keuangan dari PT. MNA yang sedang krisis ${ }^{3}$ yaitu dengan cara melakukan penambahan 2 unit pesawat Boeing 737 Family. Lalu, untuk menindaklanjuti rencana tersebut diadakanlah hubungan bisnis dengan Thirdstone Aircraft Leasing Group (TALG) Washington DC selaku pihak yang dapat menyewakan 2 jenis pesawat dengan tipe Boeing 737-500 dan Boeing 737-400.

Permasalahan terjadi ketika tidak terjadinya penyerahan 2 unit pesawat seperti yang diperjanjikan akibat wanprestasi yang dilakukan dari pihak TALG sehingga mengakibatkan kerugian sebesar US\$ 1.000.000.4 Akibat dari gagalnya terlaksana Perjanjian dengan Pihak TALG, maka mengakibatkan kerugian sebesar US\$ 1.000.000 diderita oleh PT. MNA sehingga menyeret Hotasi D.P. Nababan ke pengadilan untuk mempertanggungjawabkannya dimata hukum.

\section{Rumusan Masalah}

Berdasarkan latar belakang masalah diatas, maka yang menjadi pokok pembahasan dari penelitian ini adalah: pertama, bagaimana tanggung jawab direksi perseroan terbatas atas perbuatan melawan hukum yang dilakukan oleh direksi di Indonesia? Kedua, bagaimana upaya hukum atas kerugian perseroan akibat perbuatan melawan hukum yang dilakukan oleh Direksi dalam mengurus perseroan terbatas?

\section{Tujuan Penelitian}

Tujuan penelitian yang ingin dicapai dari penelitian ini adalah: pertama, untuk mengkaji tanggung jawab direksi perseroan terbatas atas perbuatan melawan hukum di Indonesia; Kedua, untuk mengkaji upaya hukum atas

\footnotetext{
3 Putusan Mahkamah Agung Pada Tingkat Kasasi Nomor 417 K/Pid.Sus/2014 hlm. 4.

${ }^{4}$ Ibid., hlm. 40.
} 
kerugian perseroan akibat perbuatan melawan hukum yang dilakukan oleh Direksi dalam mengurus perseroan terbatas.

\section{Metode Penelitian}

Penelitian ini termasuk ke dalam penelitian normatif dengan dengan mendasarkan data kepustakaan sebagai data utamanya. Objek penelitian berfokus kepada pertanggungjawaban direksi atas perbuatan melawan hukum yang merugikan perseroan terbatas dalam kasus Dasep Ahmadi (Direksi PT. Sarimas Ahmadi Pratama) dan Hotasi Nababan (Direksi PT. Merpati Nusantara Airline (Persero)). Bahan hukum yang digunakan dalam penelitian ini adalah bahan hukum primer seperti peraturan perundang-undangan, bahan sekunder seperti literatur, dan bahan tersier seperti kamus. Data yang diperoleh kemudian dianalisis dengan menggunakan metode deskriptif kualitatif.

\section{Hasil Penelitian dan Pembahasan}

\section{Tanggung Jawab Direksi Perseroan Terbatas atas Perbuatan Melawan Hukum yang dilakukan oleh Direksi di Indonesia}

Tugas dan tanggung jawab direksi dalam pengurusan perseroan adalah sebagai bentuk dari doktrin hukum fiduciary duty, yaitu sebuah konsep dimana direksi adalah pihak yang dipercaya oleh pihak lain dalam hal ini adalah pemegang saham, untuk bertindak dan atas nama serta demi kepentingan pihak yang memberikan kepercayaan tersebut, dengan demikian direksi berkewajiban untuk melaksanakan kepercayaan tersebut dengan itikad baik dan penuh tanggung jawab. ${ }^{5}$ Kesimpulannya setiap pengurusan perseroan oleh direksi harus mencerminkan dan tidak boleh bertentangan dengan prinsip fiduciary duty sebagaimana yang tercantum dalam UUPT.

Dalam melaksanakan kegiatan bisnis dapat diibaratkan sebagai sebuah pertaruhan besar, dalam bisnis hanya terdapat dua macam hasilnya yaitu, keuntungan atau kerugian. Setiap perseroan pasti selalu mengharapkan hasil keuntungan di dalam setiap transaksi bisnis namun risiko akan datangnya kerugian pasti terdapat dalam setiap transaksi bisnis. Hal ini sangat berkaitan erat dengan direksi yang tugas dan kewajibannya adalah mengelola manajemen perseroan, oleh karena itu direksi selalu dituntut untuk dapat membuat keputusan dengan cepat, tepat, dan cermat mengingat kondisi bisnis yang sangat dinamis.

5 Zarman Hadi, Karateristik. Tanggung Jawab Pribadi Pemegang Saham, Komisaris Dan Direksi Dalam Perseroan Terbatas, UB Press, Malang, 2011, hlm. 91. 
Berhubungan dengan kerugian tersebut, tidak selalu menjadi tanggung jawab dari direksi, adakalanya direksi dibebaskan dari segala bentuk tanggung jawab termasuk tanggung jawab secara pribadi apabila ia telah mengambil keputusan tersebut dengan berhati-hati dan juga penuh rasa tanggung jawab serta dengan itikad baik. Inilah yang disebut dengan doktrin Business Judgement Rule.

Secara Eksplisit, penerapan doktrin business judgement rule dapat ditemui dalam Pasal 97 ayat (5) UU PT, pada intinya diatur bahwa direksi tidak dapat dipertanggungjawabkan secara pribadi atas kerugian perseroan apabila dapat membuktikan:

a. kerugian tersebut bukan karena kesalahan atau kelalaiannya;

b. telah melakukan pengurusan dengan itikad baik dan kehati-hatian untuk kepentingan dan sesuai dengan maksud dan tujuan Perseroan;

c. tidak mempunyai benturan kepentingan baik langsung maupun tidak langsung atas tindakan pengurusan yang mengakibatkan kerugian; dan

d. telah mengambil tindakan untuk mencegah timbul atau berlanjutnya kerugian tersebut.

Perbuatan Dasep Ahmadi berupa menyediakan mobil listrik untuk penyelenggaraan APEC XXI 2012 yang tidak laik jalan serta yang merupakan hasil rekayasa semata jelas sebagai perbuatan yang melawan hukum, yaitu melawan ketentuan hukum yang telah diatur dalam Pasal 9 ayat (2), Pasal 68 dan Pasal 132 ayat (6) PP Nomor 55 Tahun 2012 tentang Kendaraan (PP Kendaraan).

Kendaraan listirk yang disediakan oleh Dasep Ahmadi dikatakan tidak laik jalan karena tidak memenuhi persyaratan teknis sebagaimana yang diatur dalam Pasal 9 ayat (2) PP Kendaraan yaitu kendaraan bermotor yang dioperasikan di jalan harus memenuhi persyaratan teknis, salah satunya rangka landasan yang harus dibubuhkan nomor rangka landasan yang:

a. Ditempatkan secara permanen pada bagian tertentu rangka landasan;

b. Ditulis dalam bentuk embos ke dalam atau keluar; dan

c. Mudah dilhat dan dibaca.

Selain itu kendaraan tersebut tidak memenuhi persyaratan laik jalan sebagaimana yang diatur dalam Pasal 68 PP Kendaraan yang mengatur bahwa kendaraan bermotor yang dioperasikan di jalan harus memenuhi persyaratan laik jalan, salah satunya kincup roda depan dengan standar kinerja batas toleransi lebih kurang 5 milimeter per meter $(\mathrm{mm} / \mathrm{m})$. Kendaraan listrik yang disediakan oleh Dasep Ahmadi dikatakan hasil rekayasa karena tidak sesuai dengan apa yang diatur dalam Pasal 132 ayat (6) PP Kendaraan yaitu bahwa modifikasi kendaraan bermotor hanya dapat dilakukan setelah mendapat rekomendasi dari agen tunggal pemeggal merek. 
Akibat dari perbuatan tersebut, PT. SAP mengalami kerugian, baik secara materiil maupun imateril. Secara materiil, PT. SAP tidak dapat menikmati dan memanfaatkan hasil dari pengembangan mobil listrik sebesar Rp. 28.993.818.181,00, sedangkan secara Imateriil, PT. SAP tercemar nama baiknya, sehingga pesanan pengembangan mobil listrik menjadi berkurang.

1) Perbuatan Tersebut Harus Perbuatan Melawan Hukum

Persidangan Pengadilan Tindak Pidana Korupsi pada Pengadilan Negeri Jakarta Pusat mengemukakan fakta bahwa Dasep Ahmadi yang bertindak untuk dan atas nama PT. SAP telah melakukan kesalahan serta kelalaian dengan menyediakan mobil listrik yang ternyata hasil rekayasa dan tidak laik untuk dipergunakan dalam penyelenggaraan APEC XXI 2013. Penyediaan kendaraan listrik yang merupakan hasil rekayasa tersebut melanggar ketentuan teknis dan administrasi sebagaimana yang diatur dalam PP Kendaraan.

2) Kesalahan

Kesalahan berdasarkan Pasal 1365 KUHPerdata memiliki makna sesuatu perbuatan yang tercela dan menimbulkan kerugian, maka dari itu pembuat kesalahan harus bertanggungjawab atas kerugian tersebut. Pengurusan perseroan oleh Dasep Ahmadi sepanjang mengenai penyediaan mobil listrik untuk kegiatan APEC XXI 2013 dilakukan dengan tidak menerapkan prinsip itikad baik dan tidak sesuai dengan aturan hukum yang berlaku serta anggaran dasar perseroan.

3) Kerugian

Kerugian yang timbul dari perbuatan melawan hukum meliputi kerugian harta kekayaan atau material dan ideal atau immaterial. ${ }^{6}$ PT. SAP mengalami kerugian, baik secara materiil maupun imateril. Secara materiil, PT. SAP tidak dapat menikmati dan memanfaatkan hasil dari pengembangan mobil listrik sebesar Rp. 28.993.818.181.00,00, sedangkan secara Imateriil, PT. SAP tercemar nama baiknya, sehingga pesanan pengembangan mobil listrik menjadi berkurang.

4) Hubungan Sebab-Akibat antara Perbuatan dan Kerugian

Sebab dari kelalaian dan kesalahan Dasep Ahmadi dalam mengurus perseroan, maka PT. SAP mengalami kerugian, hal tersebut merupakan satu rangkaian antara perbuatan yang mengakibatkan perseroan mengalami kerugian.

Berdasarkan konsep pertanggungjawaban direksi, sesuai Pasal 97 ayat (3) UU PT, maka Dasep Ahmadi harus bertanggungjawab secara pribadi atas kerugian tersebut, lantaran kerugian PT. SAP diakibatkan oleh pengurusan

${ }^{6}$ Purwahid Patrik, sebagaimana dikutip dalam Ridwan Khairandy, Hukum Kontrak Indonesia dalam Perspektif Perbandingan (Bagian Pertama), FH UII Press, Yogyakarta, 2013. hlm. 311. 
perseroan yang dilakukan oleh Dasep Ahmadi tidak dilakukan dengan menerapkan prinsip itikad baik dan penuh tanggung jawab. Tanggung jawab secara pribadi berarti bahwa seluruh kerugian terhadap perseroan yang diakibatkan oleh pengurusan direksi yang tidak dilandasi dengan itikad baik, harus diganti oleh direksi tersebut.

Atas kerugian perseroan, bila pengadilan menjatuhkan sanksi baik dalam bentuk sanksi perdata maupun pidana terhadap Dasep Ahmad, hal tersebut adalah sebagai bentuk pengadilan mengesampingkan konsep pertanggungjawaban terbatas pada badan hukum. Dalam kasus ini, penjatuhan sanksi pidana berdasarkan putusan Pengadilan Tindak Pidana Korupsi pada Pengadilan Negeri Jakarta Pusat terhadap Dasep Ahmadi adalah sebagai bentuk tanggung jawab secara pribadi.

Dasep Ahmadi tidak bisa mengelak dari pertanggungjawaban secara pribadi, karena ia tidak memenuhi doktrin Business Judgement Rule sebagaimana yang diatur dalam Pasal 97 ayat (5), dikarenakan kerugian yang diderita oleh PT. SAP disebabkan oleh kesalahan serta kelalaiannya Dasep Ahmadi sebagai Direksi, selain itu bentuk penyediaan kendaraan yang tidak laik jalan adalah sebagai bentuk itikad buruk serta ketidakhati-hatian Dasep Ahmadi dalam mengurus perseroan.

\section{Pembahasan Kasus Hotasi Nababan}

Kerugian senilai US\$ 1.000.000 yang dialami oleh PT. MNA akibat dari gagalnya perjanjian sewa menyewa pesawat dengan TALG mengakibatkan Hotasi Nababan sebagai direksi harus bertanggungjawab. Hotasi Nababan sejatinya sempat lolos dari tanggung jawab secara pribadi sebagaimana ketentuan Pasal 97 ayat (3) UUPT.

Berdasarkan putusan nomor: 36/Pid.B/TPK/2012/PN.JKT.PST. dari Pengadilan Tindak Pidana Korupsi pada Pengadilan Negeri Jakarta Pusat, terbukti bahwa keputusan bisnis yang diambil oleh Hotasi Nababan mengadakan hubungan hukum perjanjian sewa menyewa pesawat dengan TALG dilandasi oleh itikad baik, tidak terdapat kesalahan maupun kelalaian atau bahkan tidak terdapat unsur kepentingan. Bahkan putusan tersebut menilai bahwa Hotasi Nababan telah mengambil tindakan pencegahan agar kerugian timbul atau berlanjut.

Sebagai direksi, Hotasi Nababan telah berupaya untuk menjalankan kepengurusan perseroan dengan itikad baik dan penuh tanggung jawab. Keputusannya untuk mengadakan perjanjian sewa menyewa pesawat dengan TALG dilandasi oleh kebutuhan perseroan untuk meningkatkan pendapatan PT. MNA serta sebagai upaya untuk menyelamatkan kondisi keuangan perseroan. 
Hubungan hukum dengan TALG juga telah diperhitungkan dengan sangat hati-hati oleh Hotasi Nababan, terbukti dengan cara terlebih dahulu melakukan pemeriksaan dokumen dan fisik terhadap status hukum TALG. Terhadap pembayaran security deposit senilai US\$ 1.000 .000 melalui rekening Hume $\mathcal{E}$ Associates sebagai pihak yang ditunjuk oleh TALG dilakukan karena hal tersebut adalah kewajiban hukum PT. MNA yang telah mengadakan kesepakatan dengan TALG berdasarkan LASOT atau Nota Kesepahaman.

Hotasi Nababan juga telah berupaya mencegah timbulnya kerugian terhadap PT. MNA (dalam hal perjanjian sewa menyewa pesawat dengan TALG) yaitu dengan memasukan klasul pengembalian atau refundable dalam perjanjian, yakni berupa kewajiban terhadap TALG untuk mengembalikan security deposit senilai US\$1.000.000 kepada PT. MNA apabila TALG tidak dapat mengantar atau menyerahkan pesawat kepada PT. MNA sesuai dengan tanggal yang diperjanjikan.

Kerugian yang timbul terhadap PT. MNA sejatinya diakibatkan oleh perbuatan wanpretasi yang dilakukan oleh TALG, yaitu sampai dengan tanggal yang diperjanjikan, TALG tidak menyerahkan pesawat kepada PT. MNA. Untuk mencegah timbulnya kerugian yang berkelanjutan terhadap PT. MNA, Hotasi Nababan didampingi Kejaksaan Agung Republik Indonesia telah mengajukan gugatan secara perdata terhadap CEO TALG Alan Messner dan John Cooper, atas perbuatan wanprestasi, oleh US District Court for the District of Columbia mereka berdua diperintahkan untuk mengembalikan uang US\$ 1.000 .000 beserta bunganya kepada PT. MNA. Atas pertimbangan tersebut, Hotasi Nababan lantas lolos dari tanggung jawab secara pribadi akibat kerugian yang diderita oleh PT. MNA.

Pada 2014, keadaan berubah drastis untuk Hotasi Nababan yang divonis atas perbuatan melawan hukum secara sah dan meyakinkan melanggar Pasal 2 ayat (1) UU No. 31 Tahun 1999 jo. UU No. 20 Tahun 2001 tentang Pemberantasan Tindak Pidana Korupsi dan menjatuhkan pidana penjara selama 4 tahun serta pidana denda sebesar Rp. 200.000.000,00 subsidair 6 bulan kurungan penjara oleh Mahkamah Agung Republik Indonesia berdasarkan putusan Nomor: 417 K/Pid.Sus/2014. Ia dituntut untuk bertanggung jawab secara pribadi atas kerugian yang timbul terhadap PT. MNA akibat dari gagalnya hubungan sewa menyewa pesawat dengan TALG.

Keputusan bisnis yang dibuat oleh Hotasi Nababan dinilai oleh Mahkamah Agung dibuat dengan tidak hati-hati dan lalai, hal ini dikarenakan ia tidak cermat dalam menilai status hukum TALG dan isi perjanjian yang ada. Dalam persidangan fakta mengungkapkan bahwa security deposit senilai US\$ 1.000 .000 
justru digunakan oleh TALG sebagai uang muka untuk membeli pesawat yang akan disewakan kepada PT. MNA dari pihak lain.

Pada akhirnya, Hotasi Nababan harus bertanggung jawab secara pribadi atas kerugian yang dialami oleh PT. MNA sesuai sesuai Pasal 97 ayat (3) UU PT. Ia tidak bisa diselamatkan oleh keberadaan Pasal 97 ayat (5) UU PT atau doktrin business judgement rule. Mahkamah Agung menolak mentah-mentah seluruh pertimbangan hukum yang dikeluarkan oleh Majelis Hakim Pemeriksa Perkara pada tingkat pertama, sebaliknya Mahkamah Agung jusru menggunakan pertimbangan hukum tersebut untuk menjatuhkan sanksi pidana terhadap Hotasi Nababan.

1) Perbuatan Tersebut Harus Perbuatan Melawan Hukum

Bentuk perbuatan melawan hukum yang dilakukan oleh Hotasi Nababan ialah tidak melaksanakan tugasnya sebagai direksi PT. MNA yang mematuhi peraturan perundang-undangan serta tidak menjalakan prinsip-prinsip profesionlaisme, efisiensi, transparansi, kemandirian, akuntabilitas, pertanggungjawaban serta kewajaran sebagaimana yang ditur dalam Pasal 5 ayat (3) UU BUMN.

Secara nyata dalam kasus Hotasi Nababan, pelanggaran atas ketentuan Pasal 5 ayat (3) UU BUMN ialah keputusan Hotasi Nababan sebagai direksi PT. MNA untuk tetap melanjutkan hubungan bisnis berupa perjanjian sewa menyewa dengan TALG meski hal tersebut tidak termasuk dalam RKAP PT. MNA, serta perbuatan lalai-nya Hotasi Nababan yang tidak melaporkan atau tidak mengajukan perubahan atau tidak mengajukan persetujuan kembali kepada RUPS atas RKAP PT. MNA adalah perbuatan melawan hukum

2) Kesalahan

Keputusan Hotasi Nababan, yakni membayarkan security deposit sebesar US\$ 1.000.000 tidak melalui mekanisme letter of credit atau escrow account tetapi secara cash ke rekening Hume \& Associates tidak sesuai dengan perjanjian antara PT. MNA dan TALG. Semestinya security deposit dibayarkan setelah TALG mengamankan terlebih dahulu dari pihak ketiga pesawat yang akan disewakan kepada PT. MNA. Akibatnya, security deposit justru dapat dicairkan oleh TALG tanpa sepengetahuan PT. MNA dan sampai saat yang telah ditentukan, PT. MNA tidak pernah menerima penyerahan pesawat.

3) Kerugian

Pada kasus Hotasi Nababan, akibat perbuatan melawan hukum yang dilakukannya, kerugian sebesar US\$ 1.000 .000 (satu juta dollar Amerika Serikat) diderita oleh PT. MNA.

4) Hubungan Sebab-Akibat antara Perbuatan dan Kerugian

Sebab dari kelalaian dan kesalahan Hotasi Nababan dalam mengurus perseroan, maka PT. MNA mengalami kerugian, hal tersebut merupakan satu 
rangkaian antara perbuatan yang mengakibatkan perseroan mengalami kerugian.

Kesimpulan pada pembahasan sub bab ini adalah perbuatan melawan hukum kerap menjadi permasalahan bagi direksi dalam melakukan pengurusan perseroan, Perbuatan melawan hukum yang dilakukan oleh direksi mengakibatkan perseroan mengalami kerugian, hal tersebut terjadi dikarenakan pengurusan perseroan oleh direksi dilakukan tidak dengan itikad baik, terdapat kelalaian serta mengambil kebijakan dengan tidak menerapkan prinsip kehatihatian.

Analisis yang dilakukan oleh penulis terhadap sub.bab ini menyimpulkan bahwa Dasep Ahmadi sebagai direksi PT. SAP dan Hotasi Nababan sebagai direksi PT. MNA mengambil tanggung jawab penuh secara pribadi atas pelaranggaran fiduciary duty sebagaimana ketentuan Pasal 97 ayat (2) UU PT. Pelanggaran tersebut merupakan perbuatan melawan hukum, mengakibatkan mereka harus bertanggung jawab secara pribadi, sebagaimana ketentuan Pasal 97 ayat (3) UU PT.

\section{Upaya Hukum atas Kerugian Perseroan akibat Perbuatan Melawan Hukum yang Dilakukan Direksi}

Upaya hukum pertama yang dapat ditempuh terhadap direksi yang melakukan perbuatan melawan hukum ialah melakukan pemeriksaan terhadap perseroan, sebagaimana yang diatur dalam Pasal 138 ayat (1) angka b UU PT, pasal tersebut mengatur bahwa pemeriksaan terhadap perseroan dapat dilakukan dengan tujuan untuk mendapatkan data atau keterangan dalam hal terdapat dugaan bahwa anggota direksi atau dewan komisaris melakukan perbuatan melawan hukum yang merugikan perseroan atau pemegang saham atau pihak ketiga.

UU PT telah memberikan mekanisme terhadap pihak yang dirugikan, dalam hal ini pemegang saham untuk melakukan upaya hukum tertentu, yaitu melalui mekanisme hukum yang telah diatur dalam Pasal 61 ayat (1) UU PT dan Pasal 97 ayat (6) UU PT. Pasal 61 ayat (1) UU PT mengatur tentang gugatan langung, intinya melalui ketentuan tersebut mempersilahkan setiap pemegang saham mengajukan gugatan terhadap perseroan ke pengadilan negeri apabila dirugikan karena tindakan perseroan yang dianggap tidak adil dan tanpa alasan wajar sebagai akibat keputusan RUPS, Direksi dan/ atau Dewan Komisaris, sedangkan Pasal 97 ayat (6) UU PT mempersilahkan atas nama perseroan, pemegang saham yang mewakili paling sedikit $1 / 10$ bagian dari jumlah seluruh saham dengan hak suara dapat mengajukan gugatan melalui pengadilan negeri terhadap anggota direksi yang karena kesalahan atau kelalaiannya menimbulkan kerugian terhadap perseroan. 
Pemegang saham PT. SAP maupun PT. MNA, sebagai pihak yang dirugikan oleh Dasep Ahmadi dan Hotasi Nababan sebagai direksi yang melakukan perbuatan melawan hukum, dapat melakukan upaya hukum mengajukan gugatan secara perdata melalui mekanisme hukum yang telah diatur dalam UU PT, bila mana hal tersebut belum cukup, maka PT. SAP dan PT. MNA dapat menggunakan mekanisme hukum perdata guna melindungi hak-haknya.

Pasal 1365 KUHPerdata menentukan bahwa setiap perbuatan melawan hukum yang menimbulkan kerugian terhadap orang lain, mewajibkan kepada orang itu karena kesalahannya untuk mengganti kerugian tersebut. Apabila menggunakan perbuatan melawan hukum sebagai dasar gugatan, Rosa Agustina berpendapat bentuk tuntutan ganti kerugian yang dapat diajukan ialah:7

1. Ganti kerugian dalam bentuk uang atas kerugian yang dtimbulkan;

2. Ganti rugi dalam bentuk natura atau dikembalikan dalam keadaan semula;

3. Pernyataan bahwa perbuatan yang dilakukan adalah melawan hukum; dan

4. Melarang dilakukannya perbuatan hukum tertentu.

Jika seseorang ingin menggugat orang lain karena perbuatan melawan hukum, maka dia (penggugat) harus memenuhi persyaratan yang ditentukan Pasal 1365 KUHPerdata. M. A. Moegni Djojodirjo mengemukakan empat unsur atau syarat materiel yang dipenuhi penggugat untuk melakukan gugatan ganti rugi karena perbuatan melawan hukum. Persyaratan tersebut adalah: ${ }^{8}$

1. Perbuatan tersebut harus merupakan perbuatan melawan hukum;

2. Kesalahan (schuld);

3. Kerugian (schade); dan

4. Hubungan kausal (oorzakelijk verband).

Kesimpulan penulis pada pembahasan sub.bab ini adalah upaya hukum yang dapat dilakukan oleh perseroan (dalam hal ini PT. SAP dan PT. MNA) untuk menuntut tanggung jawab direksi atas perbuatan melawan hukum yang menimbulkan kerugian terhadap perseroan bisa ditempuh dengan menggukan mekanisme hukum sebagaimana yang diatur dalam UU PT dan KUHPerdata, karena sifat hukum perdata ialah melindungi kepentingan individu dan bertujuan untuk pemenuhan ganti kerugian bagi pihak yang dirugikan.

\section{Penutup}

Berdasarkan hasil penelitian dan pembahasan di atas, penelitian ini menyimpulkan sebagai berikut: pertama, direksi perseroan wajib mengambil

\footnotetext{
${ }^{7}$ Rosa Agustina, sebagaimana yang dikutip dalam Suhendro, Op. Cit., hlm. 194.

${ }^{8}$ M. A. Moegni Djojodirjo, sebagaimana dikutip dalam Ibid., hlm. 303.
} 
tanggung jawab penuh secara pribadi bilamana ia dalam mengurus perseroan telah melakukan perbuatan melawan hukum, terlebih akibat perbuatan tersebut perseroan mengalami kerugian. Perbuatan melawan hukum yang dilakukan oleh Dasep Ahmadi dan Hotasi Nababan menimbulkan kerugian terhadap perseroan yang mereka urus, akibatnya mereka harus mengambil tanggung jawab secara pribadi sesuai dengan ketentuan Pasal 97 ayat (3) UUPT. Kedua, upaya hukum yang dapat dilakukan oleh perseroan bilamana mengalami kerugian yang disebabkan oleh direksi yang melakukan perbuatan melawan hukum ialah mengajukan gugatan ganti kerugian secara perdata menggunakan mekanisme hukum yang telah diatur dalam Pasal 61 ayat (1) dan Pasal 97 ayat (6) UUPT dan/ atau berdasarkan Pasal 1365 KUHPerdata.

Adapun penelitian ini mengajukan saran sebagai berikut: pertama, salah satu penyebab perseroan bisa mengalami kerugian ialah karena pengurusannya oleh direksi tidak dilaksanakan dengan itikad baik dan penuh tanggung jawab, berkenaan dengan hal tersebut direksi perseroan baiknya dapat memastikan segala tindakan dan keputusan yang dibuatnya atas pengurusan perseroan tidak bertentangan peraturan perundang-undangan serta anggaran dasar perseroan. Kedua, perseroan yang dirugikan oleh direksi yang melakukan perbuatan melawan hukum ada baiknya segera mengambil tindakan untuk mencegah atau berlanjutnya kerugian, namun perseroan harus cermat mengambil tindakan hukum yang diperlukan.

\section{Daftar Pustaka}

\section{Buku}

Hadi, Zaman, Karateristik Tanggung Jawab Pribadi Pemegang Saham, Komisaris Dan Direksi Dalam Perseroan Terbatas, UB Press, Malang, 2011.

Khairandy, Ridwan, Hukum Kontrak Indonesia dalam Perspektif Perbandingan (Bagian Pertama), FH UII Press, Yogyakarta, 2013.

Sembiring, Sentosa, Hukum Perseroan Terbatas Tentang Hukum Perusahaan, Nuansa Aulia, Bandung, 2012.

Setiawan Boen, Hendra, Bianglala Business Judgement Rule, PT Tatanusa, Jakarta, 2008.

\section{Disertasi}

Suhendro, Wanprestasi dan Perbuatan Melawan Hukum dalam Kontrak di Indonesia, Disertasi, Pascasarjana Fakultas Hukum, Universitas Islam Indonesia, Yogyakarta, 2010.

\section{Putusan Pengadilan}

Putusan Mahkamah Agung Pada Tingkat Kasasi Nomor 417 K/Pid.Sus/2014. 